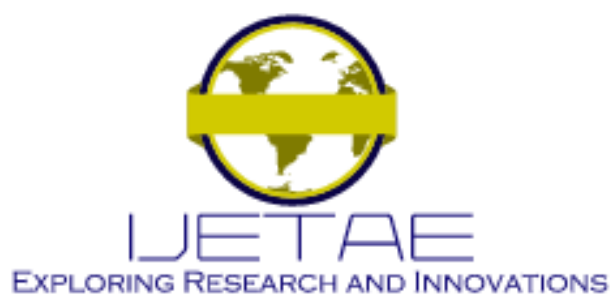

International Journal of Emerging Technology and Advanced Engineering

Website: www.ijetae.com (E-ISSN 2250-2459, Scopus Indexed, ISO 9001:2008 Certified Journal, Volume 11, Issue 06, June 2021)

Manuscript Received: 22 April 2021, Received in Revised form: 28 May 2021, Accepted: 12 June 2021

DOI: 10.46338/ijetae0621_07

\title{
The Positive Impact of Implementation Business Intelligence and Big Data in Hospitality and Tourism Sector
}

\author{
Evaristus Didik Madyatmadja ${ }^{1}$, Chairunnissa Nur Aulia Adiba ${ }^{2}$, David Jumpa Malem Sembiring ${ }^{3}$, Debri Pristinella ${ }^{4}$, \\ Augustinus Madyana Putra ${ }^{5}$ \\ ${ }^{1,2}$ Information Systems Department, School of Information Systems, Bina Nusantara University, Jakarta 11480, Indonesia \\ ${ }^{3}$ Teknik Informatika, Institut Teknologi dan Bisnis Indonesia, Indonesia \\ ${ }^{4}$ Faculty of Psychology, Atma Jaya Catholic University of Indonesia, Jakarta 12530, Indonesia \\ ${ }^{5}$ Departemen Arsitektur, Fakultas Teknik, Universitas Atma Jaya Yogyakarta, Indonesia
}

\begin{abstract}
In today's digital era, technological developments are increasingly rapid, advanced, and have an incredibly positive impact on every aspect in various sectors (especially in industry). The increase in what is being done with the internet is bound to result in the data population increasing at a very fast rate as well. The huge amount of data and of various types makes it impossible to manage, analyze, interpret, and trace traditionally making it increasingly difficult for the industry to obtain relevant, timely, and unable to perform decision-making analysis due to a lack of time to actually consume the data so the industry has to work hard and spend a lot of money to produce quality information. Business intelligence and big data are forms of implementation that can answer the needs of all the hospitality and tourism industries. The purpose of this research paper is to explore, study, and discuss the results of a comprehensive analysis of many journal articles in understanding research related to the positive impacts in hospitality and tourism sector (especially in industry) after implementing business intelligence and big data based on empirical findings by employing a systematic literature review method from academic journal articles that have been indexed in the Scopus database and the Web of Science. Business intelligence and big data play a crucial role in an organization's digital transformation attempts in general in companies in hospitality and tourism industry, thereby can create a competitive advantage and be able to encourage greater effectiveness, efficiency, and strategies to determine new business models and bring successful and useful change for numerous company businesses in hospitality and tourism industry for numerous company businesses within the in hospitality and tourism industry.
\end{abstract}

Keywords - Business Intelligence, Big Data, Hospitality, Tourism, Systematic Literature Review

\section{INTRODUCTION}

In the current era of globalization or the digital era, technological developments are increasingly rapid, advanced, and have an incredibly positive impacts in various sectors of life (especially in industry). Information technology is a part of technology that is also growing rapidly and advancing. The purpose of creating and developing information technology is to facilitate human life so that every human being can't avoid the development of existing information technology. Humans as users of information technology must be able to take full advantage of technological developments to improve the progress and welfare of life now and in the future. The information technology revolution creates a new civilization, namely a life that can't be limited by time and has become an absolute necessity that has provided many benefits, one of which is a working system (increasing the ability to analyze existing problems and make decisions) so that it can increase efficiency and effectiveness in the industry.

Hospitality and tourism are the most advanced industry in the world so their crucial role in the worldwide or international economy is beyond doubt. The evidence of advancement is very clear, which is in 1990 the number of worldwide tourists (customer) was more than 400 million people, while, in 2017 the number had expanded to 1300 million people [1]. So, in 2017, the number of worldwide tourists arise by $7 \%$, which is the highest enhancement since the worldwide financial of economic crisis in 2009 [1]. Nowadays, everyone is connected to internet anywhere and anytime to find information, share whatever they want (such as to social media), make transactions, and so on. 


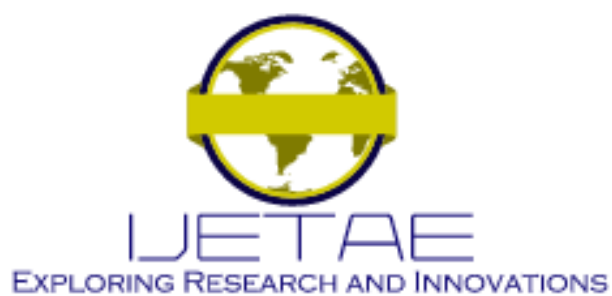

International Journal of Emerging Technology and Advanced Engineering

Website: www.ijetae.com (E-ISSN 2250-2459, Scopus Indexed, ISO 9001:2008 Certified Journal, Volume 11, Issue 06, June 2021)

Based on data from the United Nations (UN), that the number of internet users in the world in January 2021 is 4.66 billion, and also the number of social media users in the world is 4.2 billion (it is proven that the majority of internet users are social media users) [2]. One example is according to a report on world travel trends by ITB, that the internet has become the main place to buy travel tickets with a percentage of $54 \%$ of all bookings, higher than purchases with travel agents which fell by $24 \%$ [2]. The rapid growth of the internet user population and what they do with the internet is bound to result in the data population increasing at a very fast rate as well [2]. So, hospitality and tourism have become an industry that must implement sophisticated solutions professionally in their work and their implementation also requires maximum utilization of the development of information technology.

Currently, business intelligence and big data are technologies that have been widely implemented by organizations and so on because their functions are known to be related to attempts to improve their performance [2]. Business intelligence is a technology for extracting, namely converting raw data into quality information and knowledge, and also manage data and information for business analysis purposes (improve quality decision making using this technology that combines business analytics, data mining, data visualization, data tools, and data infrastructure) to encourage business to be more profitable, and able to compete in competitive market. Big data is a collection of fast processes or technologies for large, diverse, varied data quality, and complex data in a business and so on (to help in business activities) every day that are structured, semi-structured, and unstructured data. Big data has the concept of five characteristics, namely volume, velocity, variety, veracity, and value [3].

In recent years, every industry, especially hospitality and tourism industry, requires a customer-centered approach (which creates value for companies (stakeholder) and customer) that is able to understand customer needs, wants, expectations, preferences, and behavior because today's competitive advantage is driven more by the ability to anticipate, meet customer demands, improve customer satisfaction, improve competitiveness in product and service innovation, and the quality of the hospitality and tourism industry [3]. Customer plays a substantive role as the main source of information and knowledge [4].
The main problem is the huge amount of data (i.e., reservation data in the hotel rooms, flights, tourist attractions, etc.), various categories or kinds of data (structured, semi-structured, and/ unstructured data), and not having a good plan on how to use the data but still wanting to get important facts that is accurate [5]. As time goes by, the amount of data generated and stored will continue to increase in a short time. Based on the International Data Corporation (IDC), it is predicted that the amount of data from around the world will reach $175 \mathrm{ZB}$ in 2025. This makes it increasingly difficult for the industry to obtain relevantly, and timely information so that can't analyze decision-making due to lack of time to actually consume the data, which makes the industry has to work hard and spend a lot of money to produce quality information. Similarly, products and services development, machine learning, fraud prevention, and customer security are things that must also be understood and practiced.

Therefore, the above problems it is important and interesting to discuss because along with the development of the industry in the hospitality and tourism sector, a very large amount of data, various categories of data, and so on makes it difficult or impossible to manage, analyze, interpret, and track manually or traditionally (such as using 'Excel Spreadsheet') so business intelligence and big data are forms of implementation that can answer the needs of all hospitality and tourism industry. The availability of data and important information that is complete and accurate has become a major requirement for the survival of an industry [2]. Similarly, the utilization of data is seen as a disruptive innovation for hospitality and tourism industry, despite it allows organizations within the company in hospitality and tourism industry to facilitate personalization, provide easiness, reduce costs, and get on the whole competitive advantage.

Essentially, the utilize of information is seen as a troublesome development within the tourism and neighborliness industry, in spite of the fact that it permits organizations within the company within the neighborliness and tourism industry to encourage personalization, offer comfort, spare costs, and pick up an by and large competitive advantage.

What is the level (or how much) the effect or change, and what are the positive impacts in hospitality and tourism sector (especially in industry) after implementing business intelligence and big data are the main questions and focus of this research paper. 


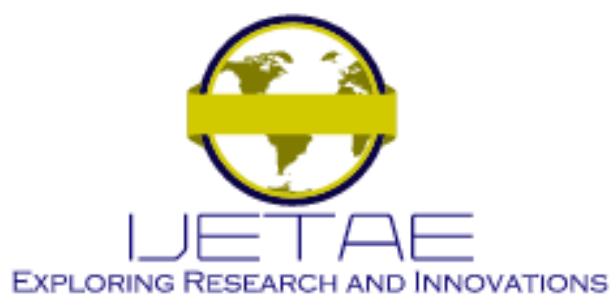

International Journal of Emerging Technology and Advanced Engineering

Website: www.ijetae.com (E-ISSN 2250-2459, Scopus Indexed, ISO 9001:2008 Certified Journal, Volume 11, Issue 06, June 2021)

This research paper, employing a systematic literature review method from academic journal articles that have been indexed in the Scopus database and the Web of Science that aims to analyze empirical findings in placing a special emphasis on how much effect or change, and the positive impacts are generated in hospitality and tourism sector (especially in industry) after implementing business intelligence and big data.

The purpose of this research paper is first to explore, study, and discuss the results of a comprehensive analysis of many journal articles in understanding research related to the positive impacts in hospitality and tourism sector (especially in industry) after implementing business intelligence and big data according to empirical findings. Besides, it also aims to open new horizons in academic research in the sector of hospitality and tourism by focused on identifying research discrepancies and future developments as well as designing agendas for future research.

The objective of the conference is to promote academic research in the hospitality and tourism industry. It is also focused on identifying areas of future research interest and developing agendas for future research.

To achieve this purpose, the following are the structure of this research paper: In section 2 'background study', contains a literature review on business intelligence and big data in general, the differences between implementation business intelligence and big data and traditional analysis in hospitality and tourism, the importance of implementing business intelligence and big data in hospitality and tourism. In section 3 'research method', describes and illustrates the research methodology used to make a systematic literature review of this research paper. In section 4 'results and discussion', contains illustrations and explanations of the main findings of this research paper review by identifying the research topic first by using conceptual and theoretical approaches, research design, data collection techniques, analysis and reporting or visualization, data features such as data sources and so on, and identify gaps in theoretical and methodological knowledge. In section 5 'conclusion', contains the main conclusions of this research paper.

\section{BACKGROUND STUDY}

\subsection{Business Intelligence and Big Data}

Business Intelligence

Business intelligence is a collection of processes or techniques, policies, culture, and a technology for collecting, manipulating, extracting, storing, visualizing, and analyzing data that has been collected and visualized into quality information from internal and external sources to create, communicate, and present accurate and organized information and knowledge in the form of easy-to-read summaries (such as reports, and/ dashboards (which contain graphs, charts, maps, etc.)) to assist users in the making of operational and strategic decisions (from identifying opportunities, threats, and performance) in business analysis to encourage the business to be more profitable and able to compete in a competitive market [6].

Business intelligence is a general term that contains a combination of [7]:

\section{1) Architectures}

Architectures of business intelligence have four constituents or components:

- Business analytics.

- Business Performance Management (BPM) that focuses only on monitoring, measuring, and comparing various performance metrics which are the core tenets of a business strategy.

- Data warehouse.

- User interface.

\section{2) Databases}

Considered the foundation of business intelligence such as how data is collected, integrated, extracted, organized, and stored.

\section{3) Analytical Tools}

Comprehensive use of data and conducting quantitative analysis are generally based on data mining and statistical analysis.

It means a technology or application that can be used in many sectors because it combines features of business analytics, data mining, data tools, data infrastructure, and data visualization [7]. 


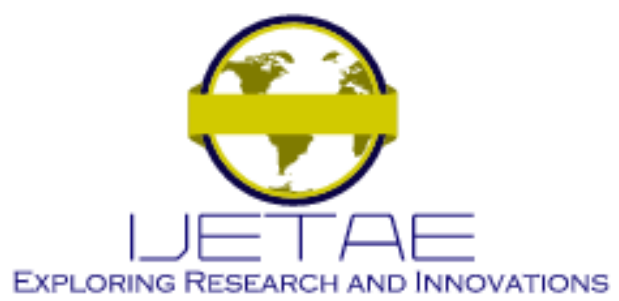

International Journal of Emerging Technology and Advanced Engineering

Website: www.ijetae.com (E-ISSN 2250-2459, Scopus Indexed, ISO 9001:2008 Certified Journal, Volume 11, Issue 06, June 2021)

Business intelligence system is a term that is generally used for technology or applications that are used to assist business intelligence activities, such as collecting data, providing access for users, analyzing data as well as information about company performance in many industries across all sectors [2]. Business intelligence system can handle various categories or kinds of data (i.e., structured, semi-structured, and/ unstructured data), very large amounts of data, and create new strategic business opportunities (from a view of historical, current, and predictive business process) [3].

The functions and features of business intelligence include: easy to carry out the reporting, OLAP, business analytics, prescriptive analytics, text mining, data mining, Business Performance Management (BPM), benchmarking, providing strategic insights into new markets, supporting customer demand assessments, and developing services for different market segments [3].

\section{Big Data}

Big data is a set of data that has a large volume and great complexity and also from various categories or kinds of data (structured, semi-structured, and/ unstructured data) that is in business every day, and over time it will continue to grow exponentially beyond the processing at traditional database system so that it is difficult or can't be processed or managed effectively with the traditional or conventional database system or other traditional techniques [8]. Basically, data that falls into the big data category is data that is large or has a volume of more than 1 tera-byte. Big data has the concept of five characteristics [9]:

1) Volume (scale)

2) Velocity (high speed and real time)

3) Variety (the different types of data)

4) Veracity (uncertainty and validity)

5) Value (the value of data)

Big data is gaining popularity today because of its ability to give companies a large and diverse amount of data, and many companies make big data technology a useful database as the main driver for value creation for stakeholders and customers, academic and non-academic research, and so on which it is possible to achieve valuable insights (regarding customer needs, wants, expectations, preferences, behaviors, and attitudes), and competitive advantage [4].

Big data is a term that is generally used to identify large volumes of data that are increasing exponentially every day (real-time) from various categories of data generated by technological developments into smaller and manageable insights that users (companies) can use [2].
The functions and features of big data include: relational nature of variables which can be common across multiple sources, very flexible in analyzing collections which can lead to easy scaling or expansion of variables and cases, high probability of finding significant correlations between two or more data sets, and a high level of detail that makes it possible to focus on specific features [3].

\subsection{The Differences Between Implementation Business Intelligence and Big Data, and Traditional Analysis in Hospitality and Tourism}

Business intelligence and big data are two of the major players in the field of data processing. Business Intelligence serves decision-makers by finding answers to questions raised by corporate businesses that are known to and would be interested in questions about the "what and where" types [10]. Meanwhile, big data can explore new possibilities to revolutionize the field of business intelligence technology and can reveal questions, answers, and perspectives that might not have been unexpected and enable "why and how" answers [10]. The records available in the data sets are classified into two class labels namely "approved" and "rejected" [1].

The Difference between Business Intelligence and Big Data:

- By implementing business intelligence, information will be stored only on a central server (data warehouse). Meanwhile, big data involves a distributed file system which makes operations more flexible and also safer data storage.

- Data processed by business intelligence is more towards the analysis of structured or semi-structured data which is mostly internal to the society and also the format is mechanically less varied. Meanwhile, big data deals with various categories or kinds of data (i.e., structured, semistructured, and/ unstructured data) from various internal and external sources.

- Business intelligence uses historical data to make decisions in the future. Meanwhile, big data can not only use historical data of past data but also real-time data.

- Analysis in business intelligence is information-oriented which is not the focus of business intelligence tools because it tends to bring data to action. Meanwhile, big data solutions focus more on processing functionality to data not the other way around.

The terms business intelligence and big data are commonly used as synonyms as they have some in common with each other or complement each other. 


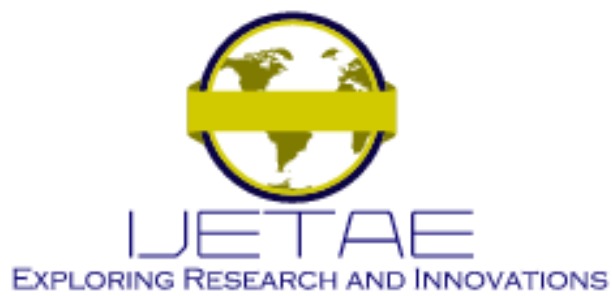

International Journal of Emerging Technology and Advanced Engineering

Website: www.ijetae.com (E-ISSN 2250-2459, Scopus Indexed, ISO 9001:2008 Certified Journal, Volume 11, Issue 06, June 2021)

However, business intelligence and big data are two different processes that occupy a unique role in the market.

The goal of business intelligence and big data is to help businesses make good decisions by analyzing large data sets to grow their business and optimize costs. Big data can be utilized for business intelligence purposes. More particularly, big data can empower business intelligence which must be elaborated appropriately although the risk of finding deceptive results or outcomes and effects is quite high (particularly if the data quality and data pre-processing are low) [3]. Therefore, business intelligence and big data are very important and must be well understood so that companies can make the best use of business intelligence and big data to achieve the desired results and value in business.

Traditional analysis challenges have driven business leaders to seek modern, forward-looking, and flexible solutions. So, the key difference and comparison of business intelligence and big data with traditional analysis in hospitality and tourism, that is by applying business intelligence and big data certainly it has a different technique than traditional analysis, it is easy to get much more informative and complex information in a structure that the data there is different characteristics, focus on different research problems, save time and resources, better achieve mission effectiveness to become a modern, databased, and insight-based company [3].

\subsection{The Importance of Implementing Business Intelligence and Big Data in Hospitality and Tourism}

The economic impact of the hospitality and tourism sector for various countries (especially developing countries) can provide guidance and benefits to service providers, policymakers, and the country itself [11]. The hospitality and tourism industry generates the country's largest revenue and income through the consumption of goods as well as services by customer, taxes, business development, job opportunities, and so on [11].

The hospitality and tourism industry revenue are greatly influenced by customer demands so having an accurate decision-making and forecasting system is very important [11].

As time goes by and the development of information technology, there are more and more business complaints in a company regarding the large amount of data it has, making it increasingly difficult to process and manage data into quality information, make decisions, and cause it to be unable to compete in the market and meet customer and company demands.
Therefore, companies are always required or indeed desire to follow the development of existing information technology so that there are no setbacks for the company by implementing sophisticated solutions, namely business intelligence and big data, where business intelligence and big data have proven to be an information technology that has an impact on the revolution industry 4.0 and plays an important role in everyday life for industries from various sectors (hospitality, tourism, banking, and so on). Basically, the potential for implementing and using business intelligence and big data for business advancement in various sectors is unlimited.

Hospitality and tourism industry is a complex system that encompasses all operations (i.e., activities, transactions, or events in hospitality and tourism market) such as web searches, web page visits, experience as well as products and services reviews (from social media (such as Twitter, Instagram, Facebook, Weibo, etc.), blogs, application as well as official websites (such as TripAdvisor, Trivago, Airbnb, Agoda, etc.), online surveys, and so on)), online ordering and purchases, and so on that can provides an inexpensive way to collect rich and authentic data so that it can generate appropriate transaction data and other data from web search data, web page visit data, online ordering and purchases data, and others [12]. Basically, customer do leave all real-time electronic traces during all such hospitality and tourism-related activities one of which can be tracked by using a GPS sensor embedded in a smartphone so that it can provide meaningful insights to hospitality and tourism marketers about the most popular routes, hotels, tourist attractions, and so on [13]. Based on the data above and also with business intelligence and big data, it can record travel stories, customer feelings, discuss hospitality and tourism recommendations, and analyze customer sentiment so that customer behavior, and the hospitality and tourism markets (determine what changes need to be made in future market offerings) can be explored and better understood by hospitality and tourism industry.

The targets that are reviewed and mostly focused on hospitality and tourism industry are hotels, restaurants, tourist attractions, and so on [12]. Reviews from customer regarding popular and unpopular hotels, tourist attractions, and so on are adopted to evaluate and improve electronic Word-Of-Mouth (e-WOM) from hotels, restaurants, tourist attractions, and so on [12]. The main reason for the popularity of the three targets previously described are lodging, meal or dining, and travel which are the top three main factors that customer pay the most attention to [12]. 


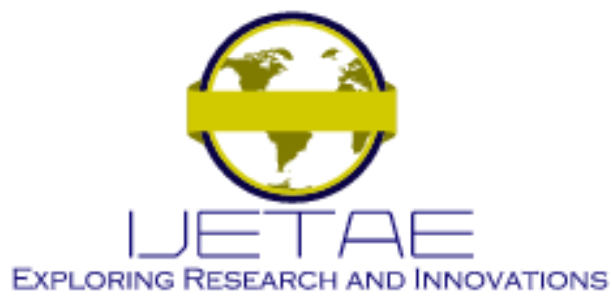

International Journal of Emerging Technology and Advanced Engineering

Website: www.ijetae.com (E-ISSN 2250-2459, Scopus Indexed, ISO 9001:2008 Certified Journal, Volume 11, Issue 06, June 2021)

Therefore, by using valuable business intelligence and big data in hospitality and tourism sector have been able to keep up with technological developments, one of which is stepping into the era of business intelligence and big data to produce extraordinary improvements.

\section{RESEARCH METHOD}

To assess the extent of business intelligence and big data features in hospitality and tourism sector. Therefore, I conducted a systematic literature review of journal articles that have been indexed in the Scopus and the Web of Science databases. A review was done in a systematic and strict standard. The purpose is not only to summarize existing research but also to include elements of analytic criticism. The results of these studies were reviewed and analyzed as data for the make of a systematic literature review of this research [21]. There are six online research databases selected to search for the journal article, namely: Science Direct, IGI Global, ACM Digital Library, Emerald Insight, and Google Scholars. The six online research databases were chosen because they had conference proceedings and journal articles on business intelligence and big data in hospitality and tourism sector. The systematic literature review method has been widely adopted in broader sciences for various sectors of life, including the hospitality and tourism sector. Thus, I used this approach to identify relevant scientific work.

Then, I manually analyze and categorize the journal articles referenced into two main groups (those related to business intelligence in hospitality and tourism sector, and related to big data in hospitality and tourism sector, (especially the positive impact of implementing both technologies)), and explored them in detail according to:

- These topics of research paper.

- The main questions and focus of this research paper.

- Conceptual and theoretical characterization.

- Data source.

The identifications mentioned above were undertaken to help me identify theoretical and methodological knowledge gaps, development needs, and promising research areas for business intelligence and big data in hospitality and tourism sector.
In addition, Science Direct, IGI Global, ACM Digital Library, and Emerald Insight, contain several important journal articles from various scientific sectors such as hospitality, tourism, business, management, innovation, technology, and so on. To improve the reliability of the results and ensure that these reviews include journal articles from a wide variety of scientific sectors, the search process is repeated using Google Scholar. Four new papers appeared as a result.

\section{RESUlt AND DisCUSSION}

\subsection{Study Found}

Searching for journal articles or papers for literature review was using the keyword "business intelligence" and "big data" and "hospitality" and "tourism", and the total number of papers is 660 papers. Subsequently, each paper is manually recorded and checked to determine its relevance to the research paper topic, namely "The Positive Impact of Implementation Business Intelligence and Big Data in Hospitality and Tourism Sector".

\subsection{Candidate Studies}

At this phase, I found 664 papers according to the abstract and the main research questions and focus of this research paper. And the result I got 31 papers selected.

\subsection{Selected Studies}

The selected articles or paper that I choose meet the following criteria:

- The research paper that focuses only on business intelligence and big data in hospitality and tourism sectors.

- The research paper discusses the level (or how much) the effect or change, and what are the positive impacts in hospitality and tourism sector (especially for the industry) after implementing business intelligence and big data.

- Articles that are relevant to the main research question and focus of this research paper.

- Articles that are published from 2009 to 2020.

- All articles are the latest research.

The result, 20 journal articles were selected because they met the review criteria which can be seen in Figure 1. Then, the data extraction, namely the number of studies from the selected papers, it can be seen in the Table 1. 


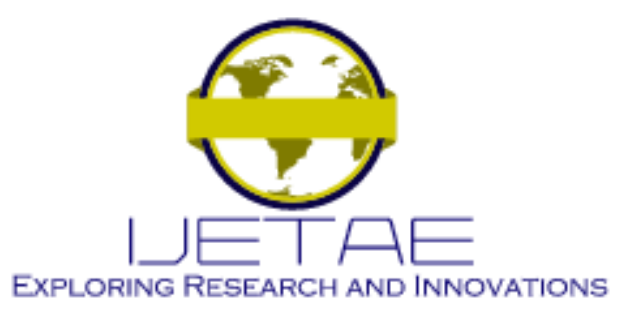

International Journal of Emerging Technology and Advanced Engineering

Website: www.ijetae.com (E-ISSN 2250-2459, Scopus Indexed, ISO 9001:2008 Certified Journal, Volume 11, Issue 06, June 2021)

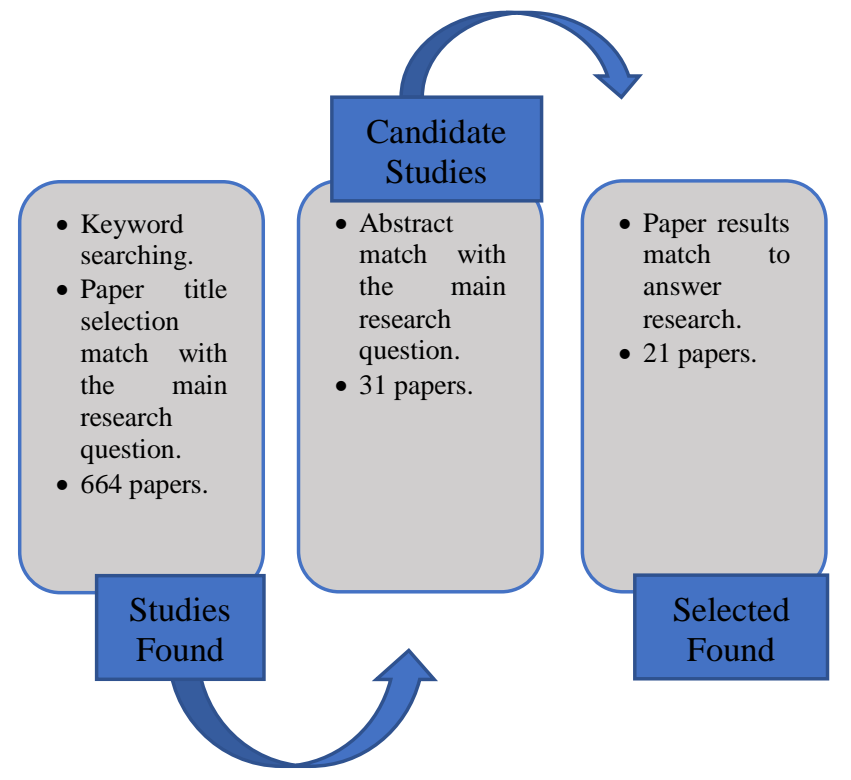

Figure 1: Searching process for systematic literature review

Table 1

The number of studies in selected sources:

\begin{tabular}{|c|c|c|c|}
\hline Source & $\begin{array}{c}\text { Studies } \\
\text { Founds }\end{array}$ & $\begin{array}{c}\text { Candidate } \\
\text { Studies }\end{array}$ & $\begin{array}{c}\text { Selected } \\
\text { Studies }\end{array}$ \\
\hline ScienceDirect & 327 & 11 & 8 \\
\hline IGI Global & 138 & 6 & 2 \\
\hline $\begin{array}{c}\text { ACM Digital } \\
\text { Library }\end{array}$ & 87 & 2 & 3 \\
\hline $\begin{array}{c}\text { Emerald } \\
\text { Insight }\end{array}$ & 108 & 11 & 7 \\
\hline $\begin{array}{c}\text { Google } \\
\text { Scholar }\end{array}$ & 4 & 1 & 1 \\
\hline Total & 664 & 31 & 21 \\
\hline
\end{tabular}

From the 21 selected papers, there are 52 authors who participated, 34 universities, and 3 institutions. Each paper is written by only one author and three authors from the same and different institutions and universities. The universities and institutions location are in Indonesia, Botswana, USA, Sweden, Thailand, Italy, Spain, Greece, UK, Australia, China, Russia, Germany, Austria, Malaysia, India.

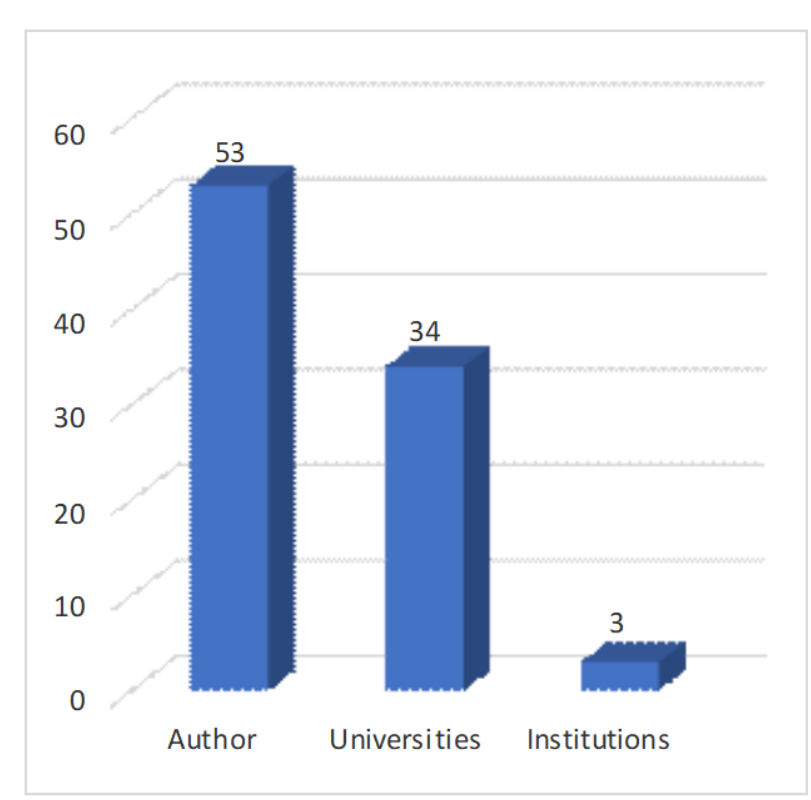

Figure 2: Author demography

All the author from the papers that I collected according to the topic of this research paper, worked in 15 different departments namely: Business, Economics, Tourism and Hospitality Management, Information systems, Signal Theory and Communications and Telematic Systems and Computation, Tourism and Service Management, Tourism Management, Science and Technology, Innovation Engineering, Leadership and Organizations Behavior, Tourism and Hospitality, Hotel and Restaurant Management, Economy and Tourism Management, Human Sciences, Mathematics and Systems Science, Political Science and Law.

Afterward, it all goes into 10 groups department, namely: Tourism and Hospitality Management, Information systems, Business, Tourism Management, Science and Technology, Innovation Engineering, Hotel and Restaurant Management, Economics, Political Science and Law, and Human Science.

The author's academic background, it can be seen in Figure 3. The author's university in the country, it can be seen in Figure 4. The papers I selected were based on the year of publication between 2009 and 2020 as shown in Figure 5. 


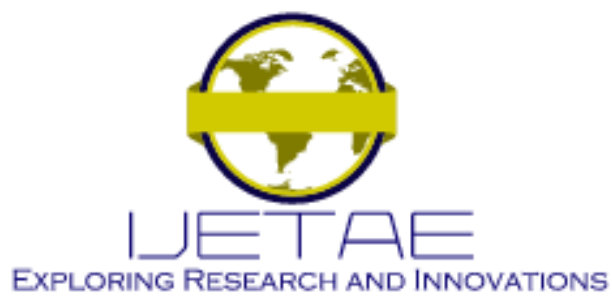

International Journal of Emerging Technology and Advanced Engineering

Website: www.ijetae.com (E-ISSN 2250-2459, Scopus Indexed, ISO 9001:2008 Certified Journal, Volume 11, Issue 06, June 2021)

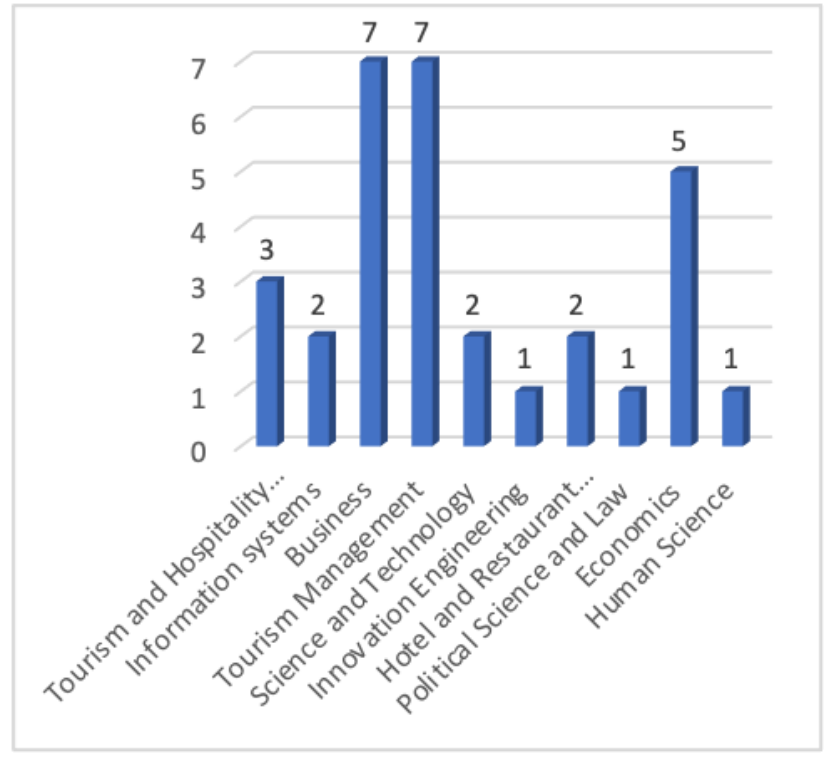

Figure 3: Author's academic background

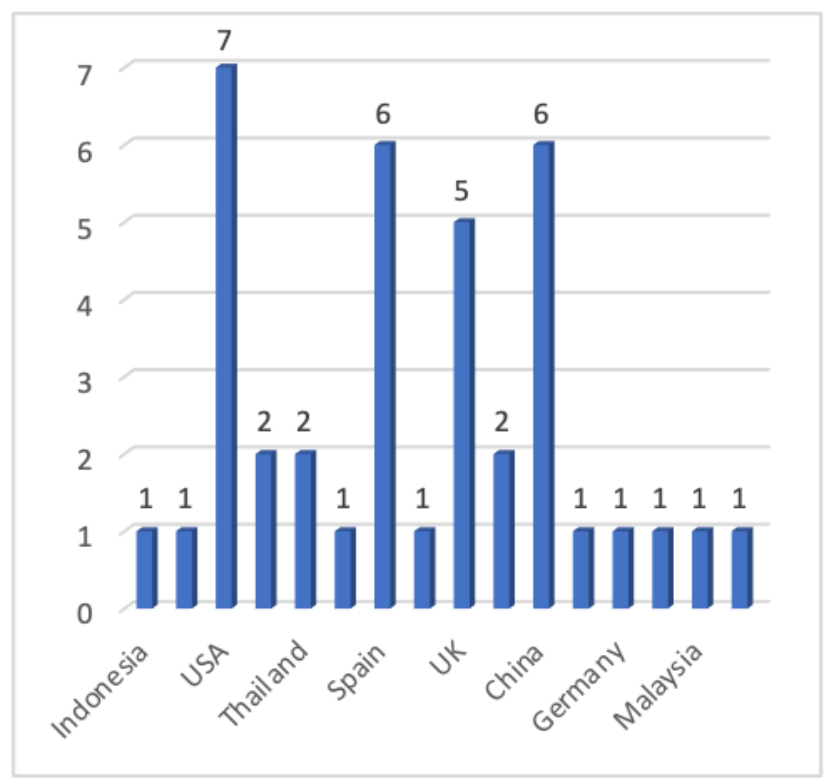

Figure 4: University in the Country

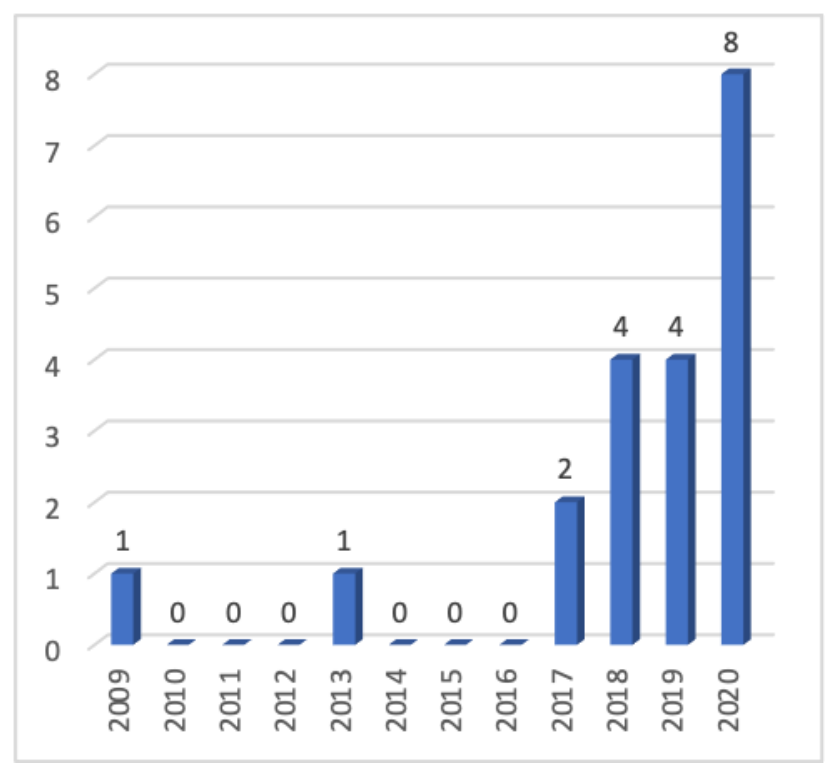

Figure 5: Publication year

4.4 A Critical Discussion on the Articles Regarding the Level (or How Much) the Effect or Change in Hospitality and Tourism Sector After Implementing Business Intelligence and Big data

Based on 20 papers or journal articles (from selected studies) that I read shows that there is a large effect or impact that has a very strong interaction between business intelligence and big data in hospitality and tourism sector (especially in industry). Business intelligence and big data play an important role in an organization's digital transformation attempts in general in companies in hospitality and tourism industry, thereby being able to encourage greater effectiveness, efficiency, and strategies to determine new business models and bring successful and useful change.

Accordingly, business intelligence and big data can create a competitive advantage for many company businesses in the hotel and tourism industry [14]. The use of customer data, if managed by companies officially of legally, ethically, and effectively can lead to that competitive advantage through greater insight into consumer behavior both online and offline [8]. 


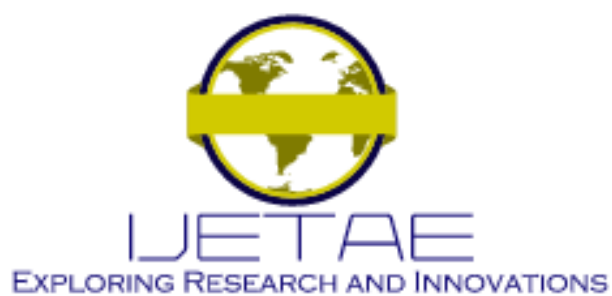

International Journal of Emerging Technology and Advanced Engineering

Website: www.ijetae.com (E-ISSN 2250-2459, Scopus Indexed, ISO 9001:2008 Certified Journal, Volume 11, Issue 06, June 2021)

Therefore, hospitality and tourism companies must assure those insights into their customer behavior do not compromise their privacy and instead give equal weight to efforts to achieve both goals [8]. These technologies will bother and design the supply chain with shifting business models and in the long run, that will result in increased efficiency and productivity [14]. New markets, including specialty markets, new destinations, and new enhanced hospitality and tourism activities will open up and promote economic growth in a more sustainable environment [14].

Specifically, in hospitality and tourism sector the effective use of business intelligence and big data is linked to revenue management (e.g., using and combining internal data (such as occupancy rates and also current bookings) with external data (such as information on local events, holiday seasons, and transportation information such as flights to forecast demand and maximize revenue)), market research and strategic marketing objectives (e.g. identifying customer trends to best meet marketing opportunities), customer experiences and reputation management (such as online reviews, services usage data, and internal feedback via customer survey) [8]. A great example of an organization that is successfully using business intelligence and big data to gain a competitive advantage is Airbnb [8].

Hospitality and tourism companies put in place and design appropriate data governance frameworks that are able to give an effective data security and protection framework for all customer and also stakeholder, and produce quality information to address growing concerns around customer data privacy and security [8]. It will become even more important in the future due to the rapid shift that is more forward-oriented and automatic. For example, in hospitality and tourism industry: international hotel chains now rely on robots to provide some of their services for example such as the Henn Na Hotel (Japan) is the first hotel in the world to be managed by a robot to deliver customer luggage to their rooms, and Hilton Hotel (USA) use robots for their concierge service [8].

\subsection{A Critical Discussion on the Articles Regarding the Positive Impacts in Hospitality and Tourism in Hospitality and Tourism Sector After Implementing Business Intelligence and Big data}

Following are the positive impacts for Hospitality and Tourism Sector (especially in industry) After Implementing Business Intelligence:

\section{1) Capture and Store Accurate Data}

Business intelligence is used to combine all different data from various sources to be processed into useful quality information [15]. By identifying industry-specific options so that the collection process yields information in sufficient quantity and quality [10]. Ideally, with a storage system in business intelligence, a hospitality and tourism management team could consolidate a company's hotel and tourism business benchmark index, which captures data from thousands of properties to see where their business stands against competitors [16].

\section{2) Store Data in a Secure and Scalable Data Warehouse}

It is imperative to put in place a scalable data warehouse that will optimize the data quickly and efficiently according to the business needs of company in the growing hospitality and tourism sector [10]. In addition, security will inevitably be attached to the data storage system [10]. So, by implementing and using business intelligence can easily detect and prevent a criminal activity such as data theft, and so on [15].

\section{3) Enable Companies to get Accurate and Organized Information}

Because the resources owned by users (companies) are allocated properly and accurately so that decisions can be made easily, quickly, and better than traditional methods [15].

\section{4) Enable Companies to Identify New Opportunities and Potential}

With the information and knowledge generated to increase the value of data and information and optimize business processes [2].

\section{5) Enable Companies to Predict and Analyze the Risks}

The risks that may arise and be experienced by companies [15]. Users also can easily change their business knowledge to solve many business problems such as to identify their most profitable customer and the reasons for their loyalty, as well as identify future customer with comparable if not greater potential [15].

\footnotetext{
6) Enable Companies to Manage Business Inventory Management Very Well

To increase efficiency and optimize operational performance [3].
} 


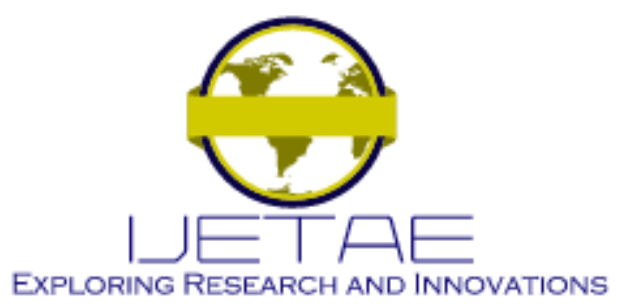

International Journal of Emerging Technology and Advanced Engineering

Website: www.ijetae.com (E-ISSN 2250-2459, Scopus Indexed, ISO 9001:2008 Certified Journal, Volume 11, Issue 06, June 2021)

\section{7) Enable Companies to Save A Lot of Time and Increase Cost Efficiency}

But still, generate a lot of revenue and profit because it can create and provide business reports that users need or want even in just seconds [15].

Following are the positive impacts for the Hospitality and Tourism Sector (especially industry) After Implementing Big data:

\section{1) Overcome Sample Size Limitations}

Large-scale big data can overcome the limitations of the sample size problems faced by survey data users, providing a new way to understand customer behavior [7]. By implementing and using big data (such as big data analytics), it will be able to provide sufficient data without sampling bias so that it can help industry, academia, and others for better understand customer behavior, and so on [17]. Therefore, big data can develop new knowledge to redesign or reshape the understanding of hospitality and tourism industry, and to espouse appropriate decisionmaking.

\section{2) Better Understanding and Analysis of Customers and Companies}

Allows a better understanding of customer needs, wants, expectations, preferences, behavior, and customer satisfaction, and other hospitality and tourism issues [9]. Hospitality and tourism companies can collect and analyze this type of data with unprecedented breadth, depth, and speed over periods of consumption that often last several days [14].

\section{3) Improve Decision-Making Process}

By synchronizing real-time information of customer experiences through the case analysis that allows obtaining insights, one of which is for hotel and tourism managers [4]. Monitoring data from social media, website and official application, blogs, and so on can make it possible to identify important features and take real-time corrective action to eliminate issues that could jeopardize the success of the case analysis process [11].

All cases also show how content analysis of negative posts or comments can be visualized through a theme that is voiced due to its frequency which allows for the identification of problems that need to be fixed or resolved instantly or in a future edition [19]. Meanwhile, positive post or comments consolidate their offering by making use of more suitable elements for planning and managing future editions [20].
4) Enable Companies in Better Project Work and Forecast

To anticipate demand, optimize Research and Development (R\&D), and improve sourcing. Forecasts can assist hospitality and tourism industry in making strategic business decisions [14].

- Big data can predict tourism demand that can be achieved, namely by using fuzzy time series and hybrid gray theory, fuzzy time series based on genetic algorithms, neuro-fuzzy techniques, agent-based modeling of customer spatial diffusion, regression models vectors, data mining techniques, multivariation statistical analysis and, so on for data analysis.

- Neural networks, classification and regression trees are used to predict hospitality and tourism loyalty by identifying attractive characteristics of the customer (such as customer service, timely responses, etc.) and implementing them in the service platform.

- Multi-factor analysis can provide a complete understanding of heterogeneous customer preferences.

To establish the optimal model for revenue forecasting tailored to the hotel and tourism company. In these ways can turn customer into loyal customer.

5) Enhance Companies Ability to Produce New Products, Services, and Business Model with Less Cost and Higher Quality

Big data can speed up or even replace daily tasks within companies. Companies that are engaged in hotel and tourism industry have a very complex back-office environment, with many tasks that must be completed simultaneously. Examples of this complexity are the assignment of tour plans, tour buses, tourist attraction programs, and so on [14].

To minimize the complexity and time of the procedure, big data in hotel and tourism companies can help customer by providing news, proposing tourism activities, hotel information and tourist attractions, and so on by enabling dynamic connections with outside stakeholders [3].

6) Help Promote Offers at The Most Appropriate Price, with The Most Appropriate Target Customer as Well

Smart price management can cope with the challenge of setting the right price in terms of time and on different distribution channels of hospitality and tourism products (such as hotel rooms and airplane seats) [14]. 


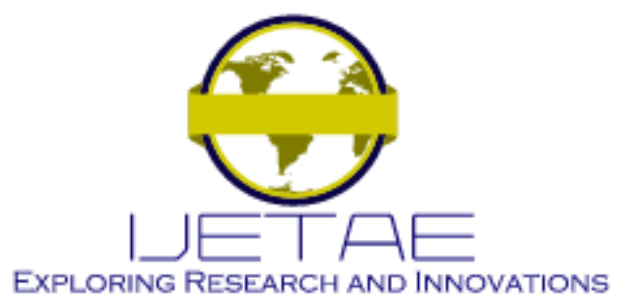

International Journal of Emerging Technology and Advanced Engineering

Website: www.ijetae.com (E-ISSN 2250-2459, Scopus Indexed, ISO 9001:2008 Certified Journal, Volume 11, Issue 06, June 2021)

That may justify the interest of hotels and airlines to use big data for strategic revenue management such as where the effects of hotel-specific factors on preferential price variables are explored. Big data offers an opportunity to capture customer preferences (regarding hospitality and tourism products) and identify market trends [4].

\section{7) Allowing Companies to Provide Convenient User experiences}

Big data can establish value and help provide an increased user experience by creating new sources and channels of value [14]. The recommendation system has become the most important tool in the marketing process. The given system combines textual content in social media messages and so on with product information, such as descriptions summarized in a catalog to provide marketing campaign recommendations [4]. Big data can make this process more convenient with many smart features and applications, such as check-in or online bookings that make lodging and physical travel more comfortable in utilizing and also collecting large amounts of valuable data [17] [14].

\section{8) Customer Experience Enhancement and Enrichment}

By searching for and anticipating needs through the analysis, then demonstrating meaningful evidence to create personalized offerings and innovations in products and services that tailor experiences based on customer demands [14]. By using and comparing social media data, website and official application, blogs, and so on customer needs, wants, expectations, preferences, and behavior can be predicted. This enables automatic monitoring of the digital experience of the customer. Analysis of digital track records (i.e., geographic location, gender, technology orientation, impressions, reach from customers, etc.) can be utilized to evaluate the attractiveness of a company and identify new market recess or target market segments as the basis for new offerings that are more focused on customer satisfaction [20].

\section{CONCLUSION}

Information technology with hospitality and tourism sector has become a fast-growing research field [17]. Based on the results and discussion of systematic literature reviews, it shows that there is a large positive effect or impact that has a very strong interaction between business intelligence and big data in hospitality and tourism sector to achieve easy consolidation, processing, interpretation of complex data, and determining patterns and correlations at various levels of aggregation of the resulting data set.
Hospitality and tourism industry is starting to use business intelligence and big data technologies, especially in product sales by monitoring and analyzing customer needs, wants, expectations, preferences, and behavior from product and service reviews (social media, blogs, websites, and applications), online surveys, online ordering and purchases, and others for making the right decisions from existing data [18]. Therefore, one of the features of business intelligence and big data in hospitality and tourism sector to improve data quality is the online track record through the use of end-user applications (i.e., mobile) which are used by millions or more people and have proven to be a source for collecting bait real-time feedback from customer, assess customer and customer behavior, track their movement patterns, make related decisions, and sharing knowledge. Similarly, with other sources, namely supplier-based knowledge from the digital destination ecosystem, can also be integrated in real-time (through product profiles and information from supplier websites and/ databases) to significantly support meeting customer demands in collaborative hospitality and the destination environment.

By implementing business intelligence and big data in various sectors (especially in hospitality and tourism sector), various benefits will be obtained for companies' businesses to maintain or increase companies' success. The impact for the hospitality and tourism sector is on various business decisions, from operational, tactical, to strategical levels such as capacity planning, resources, advertising and marketing, or tactical production planning. Business intelligence and big data have become an important part of the system of every company from various sectors (especially in hospitality and tourism sector) so that companies are required to integrate all existing systems in their companies with this process-based technology. So, business intelligence and big data need data as important indicators and variables to process the data.

From this positive impact, it can provide benefits for the company, namely the company can solve existing problems quickly, increase cost efficiency, easily analyze customer behavior and customer demands, analyze risks to create business insights (in looking for new market trends and innovation as a strategy in marketing products and sales to increase profits), improve competitiveness in product and service innovation, drive growth for competitive advantage, improve customer satisfaction, improve Customer Relationship Management (CRM), improve companies quality and also hospitality and tourism industry quality. 


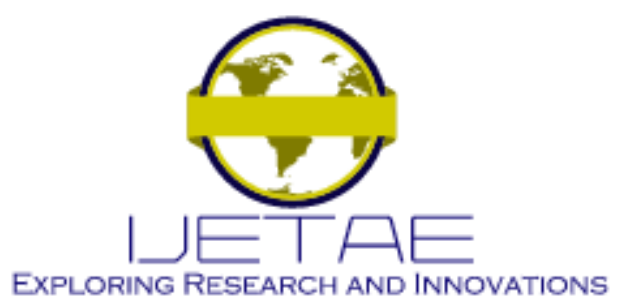

International Journal of Emerging Technology and Advanced Engineering Website: www.ijetae.com (E-ISSN 2250-2459, Scopus Indexed, ISO 9001:2008 Certified Journal, Volume 11, Issue 06, June 2021)

Table 2

List of the positive impacts

\begin{tabular}{|c|c|c|}
\hline No & The Positive Impacts & References \\
\hline 1 & $\begin{array}{l}\text { Capture and store accurate } \\
\text { data }\end{array}$ & {$[15][16]$} \\
\hline 2 & $\begin{array}{l}\text { Store data in a secure and } \\
\text { scalable data warehouse }\end{array}$ & {$[10][15]$} \\
\hline 3 & $\begin{array}{l}\text { Enable companies to get } \\
\text { accurate and organized } \\
\text { information }\end{array}$ & [15] [6] \\
\hline 4 & $\begin{array}{l}\text { Enable companies to identify } \\
\text { new opportunities and } \\
\text { potential }\end{array}$ & {$[2][10]$} \\
\hline 5 & $\begin{array}{l}\text { Enable companies to predict } \\
\text { and analyze the risk }\end{array}$ & {$[15][3]$} \\
\hline 6 & $\begin{array}{l}\text { Enable companies to manage } \\
\text { business inventory } \\
\text { management very well }\end{array}$ & [3] [10] \\
\hline 7 & $\begin{array}{l}\text { Enable companies to save a } \\
\text { lot of time and increase cost } \\
\text { efficiency }\end{array}$ & [15] \\
\hline 8 & $\begin{array}{lll}\text { Overcome } & \text { sample } & \text { size } \\
\text { limitations } & & \\
\end{array}$ & [7] [17] \\
\hline 9 & $\begin{array}{ll}\text { Better understanding } & \text { and } \\
\text { analysis of customers and } \\
\text { companies }\end{array}$ & [14] [9] [8] \\
\hline 10 & $\begin{array}{l}\text { Improve decision-making } \\
\text { process }\end{array}$ & $\begin{array}{lll}{[4]} & {[11]} & {[19]} \\
{[20]} & & \\
\end{array}$ \\
\hline 11 & $\begin{array}{l}\text { Enable companies in better } \\
\text { project work and forecast }\end{array}$ & [14] [11] [19] \\
\hline 12 & $\begin{array}{l}\text { Enhance companies ability to } \\
\text { produce new products, } \\
\text { services, and business model } \\
\text { with less cost and higher } \\
\text { quality }\end{array}$ & [14] [3] \\
\hline 13 & $\begin{array}{l}\text { Help promote offers at the } \\
\text { most appropriate price, with } \\
\text { the most appropriate target } \\
\text { customer as well }\end{array}$ & [14] [4] \\
\hline 14 & $\begin{array}{llr}\begin{array}{l}\text { Allowing } \\
\text { provide companies }\end{array} & \text { to } \\
\text { convenient } & \text { user } \\
\text { experiences } & & \\
\end{array}$ & {$[14][4][17]$} \\
\hline 15 & $\begin{array}{l}\text { Customer experience } \\
\text { enhancement and enrichment }\end{array}$ & [4] [20] \\
\hline
\end{tabular}

\section{REFERENCES}

[1] Utomo, Chandra Eko Wahyudi, "Implementasi Business Intelligent dalam e-Tourism Berbasis Big Data," Journal of Tourism and Creativity, vol. 3, no. 2, 2019.

[2] Marcello Mariani, Rodolfo Baggio, Matthias Fuchs, Wolfram Höepken, "Business intelligence and big data in hospitality and tourism: a systematic literature review," International Journal of Contemporary Hospitality Management, vol. 30, no. 12, 2018.

[3] Thanathorn Vajirakachorn, Jongsawas Chongwatpol, "Application of business intelligence in the tourism industry: A case study of a loca food festival in Thailand," Tourism Management Perspectives, vol. 23, pp. 75-86, 2017.

[4] Jingjing Li, Lizhi Xu, Ling Tang, Shouyang Wang, Ling Li, "Big data in tourism research: A literature review," Tourism Management, vol. 68, pp. 301-323, 2018.

[5] Ali Reza Alaei, Susanne Becken, Bela Stantic, "Sentiment Analysis in Tourism: Capitalizing on Big Data," Journal of Travel Research, vol. 58, no. 2, pp. 175-191, 2017.

[6] Nathaniel D. Line, Tarik Dogru, Dahlia El-Manstrly, Alex Buoye, Ed Malthouse, Jay Kandampully, "Control, use and ownership of big data: A reciprocal view of customer big data value in the hospitality and tourism industry," Tourism Management, vol. 80, 2020.

[7] Dimitra Samara, Ioannis Magnisalis, Vassilios Peristeras, "Artificial intelligence and big data in tourism: a systematic literature review," Journal of Hospitality and Tourism Technology, vol. 11, no. 2, pp. 343-367, 2020.

[8] Vecchio, Pasquale Del. "Creating value from Social Big Data: Implications for Smart Tourism Destinations," Information Processing \& Management, vol. 54, no. 5, pp. 847-860, 2018

[9] Pilar Talón-Ballestero, Lydia Gonzáles-Serrano, Cristina SogueroRuiz, Sergio Muñoz-Romero, José Luis Rojo-Álvarez " Using big data from Customer Relationship Management information systems to determine the client profile in the hotel sector," Tourism Management, vol. 68, pp. 187-197, 2018.

[10] Agustín J. Sánchez-Medina, Eleazar C-Sánchez, "Using machine learning and big data for efficient forecasting of hotel $\mathrm{T}$ booking cancellations," International Journal of Hospitality Management , vol. 89, 2020.

[11] Panchapakesan Padma, Jiseon Ahn, "Guest satisfaction \& dissatisfaction in luxury hotels: An application of big data," International Journal of Hospitality Management, vol. 84, 2020.

[12] Minwoo Lee, Seonjeong (Ally) Lee, Yoon Koh, "Multisensory experience for enhancing hotel guest experience: Empirical evidence from big data analytics," International Journal of Contemporary Hospitality Management, vol. 31, no. 11, pp. 4313-4337, 2019.

[13] Shun Ying, Jin Hooi Chan, Xiaoguang Qi, "Why are Chinese and North American guests satisfied or dissatisfied with hotels? An application of big data analysis," International Journal of Contemporary Hospitality Management, vol. 32, no. 10, pp. 32493269, 2020.

[14] A.Mazanec, Josef "Hidden theorizing in big data analytics: With a reference to tourism design research," Annals of Tourism Research, vol. 83, 2020. 


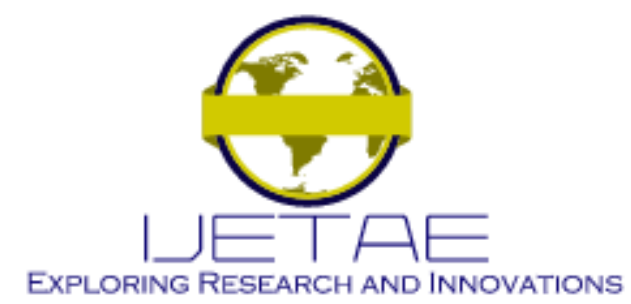

International Journal of Emerging Technology and Advanced Engineering Website: www.ijetae.com (E-ISSN 2250-2459, Scopus Indexed, ISO 9001:2008 Certified Journal, Volume 11, Issue 06, June 2021)

[15] Christopher Nyanga, Jaloni Pansiri and Delly Chatibura, "Enhancing competitiveness in the tourism industry through the use of business intelligence: a literature review," Journal of Tourism Futures, vol. 6, no. 2, pp. 139-151, 2019.

[16] Anca Yallop, Hugues Seraphin, "Big data and analytics in tourism and hospitality: opportunities and risks," Journal of Tourism Futures, vol. 6, no. 3, pp. 257-262, 2020.

[17] Mariani, Marcello "Big Data and analytics in tourism and hospitality: a perspective article," Tourism Review, vol. 75, no. 1, pp. 299-303, 2019.

[18] Shahini, Rei, "Business Intelligence in the Hotel Industry," 2020.

[19] Diane Korte, Thilini Ariyachandra, and Mark Frolick, "Business Intelligence in the Hospitality Industry," International Journal of Innovation, Management and Technology, vol. 4, no. 4, pp. 429-434, 2013.
[20] RANJAN, JAYANTHI, "BUSINESS INTELLIGENCE: CONCEPTS, COMPONENTS, TECHNIQUES AND BENEFITS," Journal of Theoretical and Applied Information Technology, vol. 9, no. 1, pp. 60-70, 2009.

[21] E. D. Madyatmadja, H. Nindito, D. Pristinella "Citizen Attitude: Potential Impact of Social Media Based Government," ICEEL 2019: Proceedings of the 2019 3rd International Conference on Education and E-Learning, pp. 128-134, 2019.

[22] E.D. Madyatmadja, M. Aryuni, "Feature selection in credit scoring model for credit card applicants in XYZ bank: A comparative study," International Journal of Multimedia and Ubiquitous Engineering, vol. 10, no. 5, pp. 17-24, 2015. 